\title{
TEORI PIAGET DALAM PEMBELAJARAN MATEMATIKA
}

\author{
Marizka Aulia Fahma*1, Jayanti Putri Purwaningrum² \\ ${ }^{1,2}$ Universitas Muria Kudus \\ marizkaauliafahma@gmail.com*1, jayanti.putri@umk.ac.id ${ }^{2}$ \\ *Corresponding Author
}

Received 31 December 2020; revised 12 May 2021; accepted 27 May 2021.

\begin{abstract}
ABSTRAK
Tujuan penyusunan artikel tentang teori Piaget dalam pembelajaran matematika adalah untuk menambahkan wawasan dalam pembelajaran matematika terkait pentingnya pemahaman konsep. Misalnya dalam memahami materi operasi penjumlahan, lebih baik siswa tidak hanya mengetahui tentang operasi penjumlahan saja, namun siswa dapat mengetahui konsep awal dari menentukan hasil operasi penjumlahan. Perkembangan zaman dan teknologi membuat banyak siswa tergantung pada penggunaan alat bantu hitung seperti kalkulator, sehingga siswa cenderung malas untuk memecahkan masalah dengan menggunakan rumus ataupun menggunakan alat peraga. Siswa tidak terlalu menyukai materi matematika karena bagi siswa matematika adalah ilmu hafalan dan sulit bagi mereka untuk menyelesaikan permasalahan matematika. Metode yang digunakan dalam penyusunan artikel ini adalah studi literatur mengenai teori Piaget dan pembelajaran materi operasi penjumlahan. Piaget mengatakan bahwa guru matematika harus mengetahui perkembangan kognitif terhadap anak. Tingkat perkembangan intelektual yang dilakukan oleh setiap individu yaitu tingkat sensosi-motor (0-1 tahun), pra-operasional (2-7 tahun), operasional konkret (7-11 tahun), dan operasional formal (11 tahun ke atas). Hasil dari studi literatur diperoleh bahwa teori piaget yang diterapkan dalam pembelajaran matematika pada materi operasi penjumlahan dengan menggunakan alat peraga mampu mengasah kreativitas, pola pikir siswa, dan meningkatkan keaktifan siswa kelas satu SD.
\end{abstract}

Kata kunci: operasi penjumlahan, pembelajaran matematika, teori Piaget.

\begin{abstract}
The purpose of making articles on Piaget's theory in mathematics learning is to add insight into mathematics learning regarding the importance of understanding concepts. For example, in understanding the material of addition operations, it is better for students not only to know about addition operations, but students can know the initial concept of determining the results of addition operations. The development of times and technology makes many students
\end{abstract}




\section{Marizka Aulia Fahma, Jayanti Putri Purwaningrum}

depend on the use of calculating tools such as calculators, so that students tend to be lazy to solve problems using formulas or using teaching aids. Students do not really like mathematics material because for students mathematics is a science of memorization and it is difficult for them to solve math problems. The method used in the preparation of this article is a literature study on Piaget's theory and learning material addition operations. Piaget said that mathematics teachers must know the cognitive development of children. The level of intellectual development carried out by each individual is the motor-sensory level (0-1 years), pre-operational (2-7 years), concrete operations (7-11 years), and formal operations (11 years and over). The results of the literature study showed that Piaget's theory which is applied in mathematics learning in addition operation material using teaching aids is able to hone creativity, students' thinking patterns, and increase the activeness of first grade elementary school students.

Keywords: addition operations, mathematics learning, Piaget's theory.

\section{PENDAHULUAN}

Belajar merupakan hal sangat penting bagi semua orang, pemerintah Indonesia sudah mengeluarkan PP tentang pemerintah daerah yang dapat meningkatkan jenjang pada program wajib belajar hingga 12 tahun (Hasanah \& Jabar, 2017). Anak dinyatakan berhasil dalam belajar tergantung pada prosesnya. Metode belajar dapat dilakukan baik dengan cara belajar mandiri atau kelompok, belajar di rumah atau di sekolah, belajar dengan bapak/ibu guru atau dengan bimbingan orang tua, dan proses belajar bisa lebih baik tergantung pada kemauan anak untuk berusaha menjadi lebih baik. Untuk menjadikan anak dapat berperilaku dan berinteraksi dengan masyarakat sekitar secara baik, dibutuhkan kemampuan komunikasi yang baik. Hal tersebut dapat diperoleh dengan belajar. Oleh karena itu, belajar memang selalu berkaitan dengan tingkah laku dan kepribadian seorang anak (Ibda, 2015).

Guru sangat berperan di dunia pendidikan dalam pencapaian tujuan pembelajaran yang diharapkan. Tugas guru adalah memberikan layanan kepada peserta didik dalam mencapai tujuan belajar dengan baik agar peserta didik bisa memanfaatkan waktu dalam pembelajaran dengan baik (Sopian, 2016). Oleh karena itu, untuk menciptakan suasana belajar yang lebih aktif tidak berpusat pada guru (student dominated class), menciptakan suasanan menyenangkan dalam belajar sehingga siswa tidak bosan dengan materi yang disampaikan guru di kelas, 
maka perlu diterapkan metode belajar yang tepat bagi siswa. Kenyataannya, masih banyak ditemui guru menyampaikan materi dengan cara konvensional dalam pembelajaran matematika. Guru cenderung lebih berperan aktif dalam proses pembelajaran dibandingkan siswa (Biantoro, Kristanti, \& Mursyidah, 2020). Hal tersebut membuat siswa tergantung pada guru dalam menghimpun informasi terkait materi pembelajaran sehingga dapat memperlambat perkembangan aspek kognitif, psikomotorik, dan afektif siswa. Siswa juga menjadi tidak terbiasa berpikir kreatif dan kritis. Kebanyakan siswa pada saat pemecahan masalah masih merasa bingung sehingga diharapkan siswa bertanya, namun terkadang siswa juga merasa kesulitan untuk bertanya. Padahal belajar seharusnya tidak hanya dipandang sebagai proses memberikan atau menyalurkan pengetahuan yang dimiliki oleh guru kepada siswa, namun ada timbal balik sehingga siswa juga harus berperan aktif.

Pengetahuan matematika meliputi kemampuan memecahkan masalah, kemampuan bernalar, konsep, algoritma, keterkaitan antar konsep, dan dapat mengkominikasikan ide serta gagasan. Tertera dalam Permendiknas No 22 tahun 2006 bahwa tugas utama guru matematika adalah membimbing dalam menemukan cara memecahkan masalah yang mungkin sulit bagi siswa, serta membimbing siswa tentang cara belajar yang benar sehingga dengan hal tersebut siswa dapat menggunakannya di masa akan datang (Manullang, 2014). Oleh karena itu, tujuan pembelajaran jangka panjang yaitu untuk menciptakan kompetensi para siswa, jika sudah lulus dari sekolah yang sudah ditempuh dan dapat mengembangkan serta memecahkan permasalahan yang akan muncul di kemudian hari.

Salah satu tantangan besar guru matematika adalah dalam memberikan pemahaman dasar yaitu tentang materi penjumlahan pada siswa kelas 1 Sekolah Dasar (SD). Penjumlahan adalah operasi dasar yang harus dapat dipahami dengan baik oleh siswa sejak kelas 1 SD. Namun kenyatannya, masih banyak dijumpai siswa yang kesulitan melakukan operasi penjumlahan meskipun sudah berada di kelas lebih tinggi (Sutrisno, 2015). Kesulitan siswa dalam menemukan hasil masalah penjumlahan disebabkan perbedaan pola pikir yang dimiliki masingmasing siswa. Ada kalanya siswa lebih cepat memahami materi yang diajarkan 
oleh guru, namun ada juga siswa yang sulit untuk menangkap materi yang diajarakan tersebut. Untuk itu, dibutuhkan metode pembelajaran yang tepat dalam menciptakan suasana pembelajaran yang lebih aktif bagi semua siswa.

Berdasarkan permasalahan yang ada, diperlukan metode pembelajaran matematika materi penjumlahan dengan menggunakan alat peraga yang dapat menjadikan siswa lebih aktif dibandingkan guru, yaitu dengan mengembangkan pemahaman konsep, potensi, dan penalaran berpikir kritis terhadap siswa. Oleh karena itu, disusun artikel tentang penerapan teori Piaget dalam pembelajaran matematika untuk menemukan konsep penjumlahan menggunakan alat peraga bagi siswa kelas $1 \mathrm{SD}$.

\section{METODE PENELITIAN}

Metode yang digunakan dalam penelitian adalah studi literatur. Penelitian studi literatur atau studi kepustakaan adalah penelitian dengan menghimpun data dan informasi dari berbagai sumber komperhensif seperti buku, artikel ilmiah dengan kredibilitas tinggi, dan karya-karya ilmiah terdahulu lain. Metode studi literatur dapat digunakan untuk menyusun kerangka sebuah penyelesaian ketika menghadapi sebuah permasalahan, serta dapat digunakan sebagai landasan untuk menemukan teori baru (Rizkita \& Supriyanto, 2020).

Dalam penelitian mengenai teori Piaget pada pembelajaran matematika materi pejumlahan bagi siswa kelas 1 SD dengan bantuan alat peraga, dihimpun teori-teori serta data-data penelitian terdahulu yang relevan bersumber dari artikel di jurnal ilmiah sebagai sumber primer dan buku-buku. Dengan ini diharapkan diperoleh hasil yang dapat dipertanggungjawabkan sebagai solusi dan referensi bagi permasalahan yang ada.

\section{HASIL PENELITIAN DAN PEMBAHASAN}

Piaget lahir di Neuhatel, Swiss, pada tanggal 9 agustus 1989. Ayahnya bernama Arthur Piaget yaitu seorang profesor pada abad pertengahan dengan spesialis ahli sejarah. Sedangkan ibunya bernama Rebecca Jackon yang memiliki sifat takwa, intelegent, dan dinamis. Piaget tertarik dengan alam pada saat beranjak muda, dan gemar mengamati binatang-binatang. Dengan hal tersebut 
Piaget sangat tertarik pada pelajaran biologi di sekolah sebab dia menyukai alam bebas. Pada saat usia 10 tahun, Piaget sudah berkarya dengan karya pertama yang diterbitkan dalam majalah ilmu pengetahuan alam tentang burung pipit albino. Pada saat berusia 15 tahun, Piaget ditawari sebagai kurator moluska yang bertempat di museum ilmu pengetahuan alam di Geneva karena Piaget sudah mulai belajar dan menerbitkan seri karangan tentang moluska dengan sangat bagus saat itu. Tawaran tersebut Piaget tolak sebab dia harus menyelesaikan sekolah terlebih dahulu. Setelah lulus sekolah menengah, Piaget melanjutkan ke Universitas Neuchatel. Pada saat itu, Piaget giat menulis dan belajar yang mengakibatkan dia sering sakit-sakitan dan mengharuskan cuti selama setahun ke pegunungan untuk kembali memulihkan diri. Piaget menuliskan filsafat saat kembali ke Neuchatel.

Pada usia 21 tahun, Piaget mendapat gelar doctoral (Ph.D) dalam geologi dan menaruh perhatian pada epitemologi (cabang filsafat tentang hakikat pengetahuan). Dengan cara mempelajari tentang anak-anak menurutnya akan menyelesaikan tentang pertanyaan-pertanyaan epistimologi. Tiga aspek yang dikemukakan oleh Piaget (berkaitan dengan struktur, isi, dan fungsi) merupakan aspek pertumbuhan intelektual. Untuk mencapai suatu operasi pada perkembangan struktur dan perkembangan operasi memerlukan adanya tindakan. Tindakan reversible, internalisasi, tidak ada yang berdiri sendiri, dan selalu tetap dinamakan operasi. Sedangkan organisasi mental tingkat tinggi, dengan kata lain satu tingkat lebih tinggi dari operasi dinamakan struktur-struktur. Isi pertumbuhan intelektual merupakan pola perilaku anak yang tertanam pada dirinya serta dilakukan pada saat merespon masalah yang dihadapi.

Perkembangan intelektual mempunyai dua fungsi yang mendasari yaitu fungsi organisasi dan fungsi adaptasi (Gradini, 2013). Adaptasi adalah asimilasi dan akomodasi yang masih terkait antara keduanya (Lefa, 2014). Pada asimilasi, seseorang menggunakan struktur yang sudah ada dalam mengadakan respon terhadap tantangan lingkungan, sedangkan dalam proses akomodasi seseorang memerlukan modifikasi struktur yang ada untuk tujuan yang sama.

Tingkat perkembangan intelektual individu terdiri dari tingkat sensosimotor (0 - 1 tahun), pra-operasional (2-7 tahun), operasional konkret (7-11 tahun), 
dan operasional formal (11 tahun ke-atas) (Hidayati, 2012). Setiap anak melalui masing-masing tingkatan tersebut, namun dengan kecepatan yang berbeda-beda. Lima faktor yang mempengaruhi perkembangan intelektual yaitu proses ekuilibrasi, pengalaman, transmisi sosial, kedewasaan, dan pengalaman logika matematik. Piaget mengemukakan tentang 3 bentuk pengetahuan, antara lain pengetahuan logika matematik, pengetahuan fisik, dan pengetahuan sosial. Pengetahuan sosial dapat diciptakan dari pikiran guru terhadap pikiran siswa, sedangkan pengetahuan fisik dan pengetahuan logika matematik harus diciptakan oleh diri sendiri. Cara untuk membangun pengetahuan ini adalah dengan akulibrasi. Menurut Paiget dan para kontruktivis mengemukakan bahwa guru seharusnya memperhatikan pengetahuan yang dimiliki siswa sebelumnya dalam proses belajar. Sebelum proses untuk mengubah gagasan anak yang sudah ada yang mungkin "salah” proses dimana gagasan-gagasan guru dipindahkan pada siswa, itu yang diterapkan dalam mengajar. Penggunaan siklus belajar digunakan sebagai salah satu strategi mengajar untuk menerapkan model konstruktivis. deskritif, empiris-induktif, dan hipotesis-desuktif merupakan tiga macam siklus belajar.

Menurut teori Piaget, guru matematika harus mengetahui tentang perkembangan kognitif siswa yang bergantung kepada siswa itu aktif atau tidak dalam berinteraksi dengan lingkungannya (Shadiq \& Mustajab, 2011). Alhaddad (2012) beranggapan bahwa matematika adalah ilmu tentang berpikir logika dan penalaran yang sistematis. Pembelajaran matematika adalah pembelajaran yang kebanyakan tidak disukai oleh siswa. Siswa beranggapan matematika adalah materi hafalan tentang rumus-rumus. Hal itu menjadi salah satu alasan kebanyakan siswa tidak menyukai matematika dan beranggapan matematika adalah pelajaran yang sulit (Anti, et al., 2017).

Kenyataannya, matematika adalah ilmu yang banyak ditemukan penerapannya dalam kehidupan sehari-hari, misal dalam jual beli dan lain-lain. Ojose (2008) mengemukakan bahwa dengan meningkatkan minat anak supaya gemar dalam mempelajari matematika, dapat dimulai dari pengenalan angka oleh orang tua. Misal pertama, perkenalkan anak urutan angka dan cara membaca angka yang benar. Pada tingkat anak usia 2 hingga 7 tahun anak belum mampu 
mengetahui secara luas tentang operasi penjumlahan atau pun pengurangan. Untuk itu, anak yang berusia 2 hingga 4 tahun proses belajarnya lebih ke proses hafalan (Mu'min, 2013). Misalkan anak yang berusia 3 tahun sedang diajarkan oleh gurunya tentang matematika materi penjumlahan yaitu $1+1=2,2+2=$ 4, dengan itu anak hanya bisa menyimpulkan bahwa hasil dari penjumlahan tersebut sebagaimana yang diberikan contoh oleh guru. Jadi, untuk anak dengan usia berkisar 2-4 pemahaman itu lah yang dimiliki tanpa mengetahui secara jelas tentang operasi-operasi seperti penjumlahan, pengurangan, dan lain-lain. Sehingga pada tingkat pra-operasional, terbagi menjadi 2 sub-tingkat yaitu sub-tingkat pertama (anak yang berusia antara 2 hingga 4 tahun) yang disebut sub-tingkat pralogis, sedangkan sub-tingkat ke-dua adalah anak berusia antara 4 hingga 7 tahun yang disebut tingkat berpikir intuitif (Basri, 2018). Berbeda dengan anak berusia berkisar 7 hingga 11 tahun, pada usia ini anak mulai berpikir rasional, berarti anak memilih operasi-operasi logis yang dapat diterapkan pada masalah-masalah konkret.

Apabila anak menghadapi suatu pertentangan antara pikiran dan persepsi, maka anak memilih pengembalian keputusan logis (Jaenudin, 2018). Pada hal ini, anak tidak mengambil keputusan perseptual seperti anak belum mengetahui materi abstrak. Anak dalam periode ini bukan berarti lebih pandai daripada anak-anak pra-sekolah. Namun, mereka bisa memecahkan masalah-masalah yang sebelumnya belum bisa diselesaikan dengan benar. Karena berpikir operasional konkret lebih stabil dibandingkan dengan berpikir statis dan impresionistis yang ada pada anak pra-operasional (Juwantara, 2019). Anak dalam periode ini dapat menyusun suatu urutan dalam objek, misalnya menggunakan benda-benda seperti permainan, kayu, atau menggunakan lidi. Untuk itu, yang sesuai dalam penerapan Piaget adalah dengan tingkat operasional konkret. Menurut Mauluah (2012), pembelajaran matematika dapat diberikan dengan bantuan alat peraga sederhana. Seperti pada materi perkalian atau penjumlahan berulang, dapat digunakan jajanan kecil misal permen untuk memperagakan kepada siswa dengan cara seperti berjualan.

Untuk menciptakan suasana belajar yang menyenangkan dan menjadikan siswa menjadi lebih aktif dibandingkan guru (student dominated class) dan supaya 
siswa tidak cepat bosan dengan apa yang ajarkan di kelas, diperlukan metode belajar yang tepat. Guru dapat menciptakan alat peraga yang menarik minat belajar matematika siswa, termasuk dalam mempelajari materi penjumlahan. Suwarto (2017) menjelaskan bahwa alat peraga yang baik digunakan untuk pembelajaran matematika materi penjumlahan jenjang sekolah dasar adalah dengan menggunakan benda konkret, seperti lidi. Pembelajaran matematika menggunakan lidi dalam materi penjumlahan dapat mengasah pikiran siswa saat memecahkan masalah, dapat membatu siswa dalam pembelajaran operasi hitung penjumlahan, dan dapat menjadikan siswa menjadi lebih aktif di kelas.

Langkah-langkah yang dapat dilakukan dalam proses pembelajaran matematika materi operasi hitung penjumlahan pada siswa kelas 1 SD dengan bantuan alat peraga adalah:

1. Guru menjelasakan materi tentang operasi penjumlahan.

2. Apabila ada siswa yang belum terlalu paham mengenai operasi penjumlahan, guru dapat menggunakan alat peraga berupa lidi mengingat tingkat pemahaman siswa berbeda-beda. Cara menggunakan alat peraga lidi untuk pembelajaran operasi penjumlahan sebagai berikut:

a. Guru menyiapkan alat peraga berupa lidi terlebih dahulu.

b. Selanjutnya guru menuliskan contoh soal yang dibuat untuk dituliskan di papan tulis supaya siswa tidak lupa soal yang diberikan.

c. Misal diberikan soal operasi penjumlahan $2+2=\ldots$, kebanyakan siswa kemungkinan sudah mengetahui hasil dari soal tersebut, namun belum mengetahui konsep dari penyelesaian (Sugriani, 2019). Dengan menggunakan alat peraga lidi, guru mengambil lidi pertama sebanyak 2 biji dan pengambilan ke dua sebanyak 2 biji seperti Gambar 1.

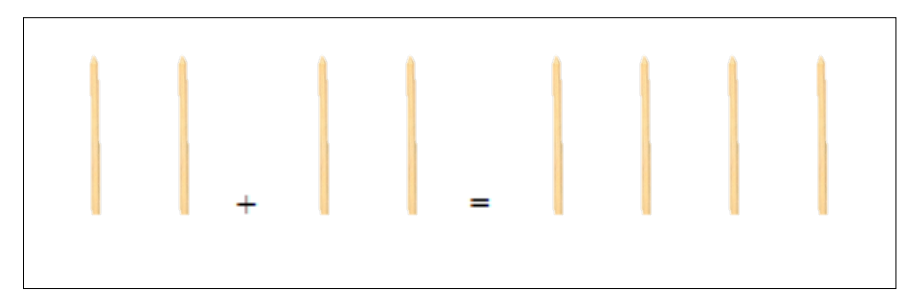

Gambar 1. Penyelesaian Contoh Soal Menggunakan Alat Peraga 
d. Lalu untuk mengembangkan keaktifan siswa, guru menyuruh siswa untuk menghitung lidi yang dibawa oleh guru tersebut. Apabila ada siswa yang benar dalam menyelesaikan masalah tersebut, guru memberikan apresiasi kepada siswa tersebut untuk menambah semangat belajar siswa dalam mempelajari operasi penjumlahan.

e. Setelah guru memberikan penjelasan materi dan cara penggunaan alat peraga, guru membagi siswa dalam kelompok untuk meningkatkan kerjasama siswa, menambah wawasan tentang penggunaan alat peraga, dan menambah keaktifan siswa dalam pembelajaran operasi penjumlahan. Misal pembahasan untuk kegiatan kelompok. Andre mempunyai lidi sebanyak 4 biji dan andre membeli lidi lagi sebanyak 5 biji lagi, berapa jumlah lidi Andre saat ini ?

Penyelesaian:

\section{Langkah I}

Diketahui:

Lidi pertama yang Andre beli: 4 biji lidi

Andre membeli lidi lagi sebanyak: 5 biji lidi

Ditanya:

Berapa jumlah lidi Andre seluruhnya?

\section{Langkah II}

Lidi pertama yang dibeli Andre.

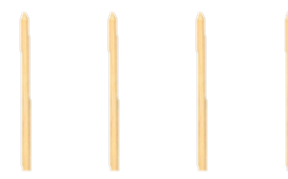

Lidi ke-dua yang dibeli Andre

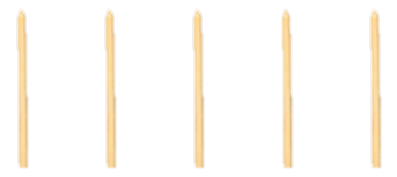

\section{Langkah III}

Untuk mengetahui jumlah lidi Andre seluruhnya gunakan operasi penjumlahan dengan cara:

Lidi pertama yang dibeli Andre + Lidi ke-dua yang dibeli Andre 


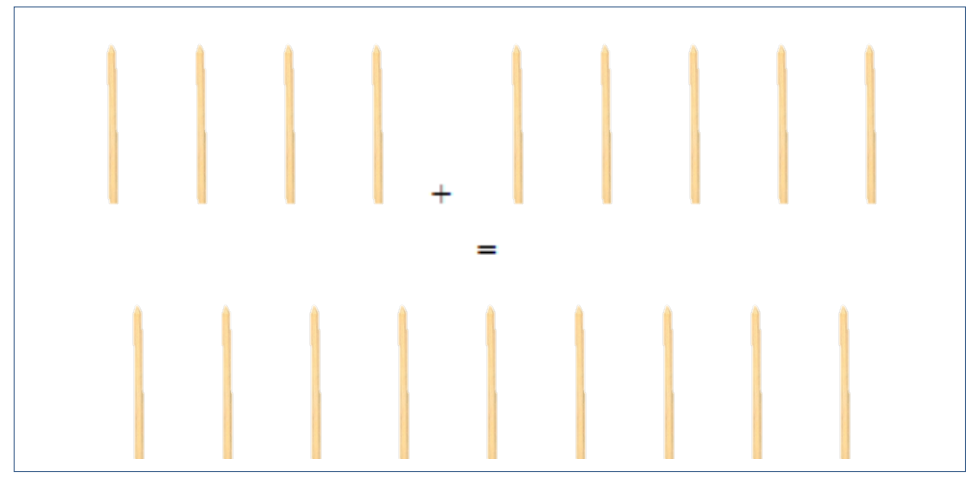

Gambar 2. Penyelesaian Menggunakan Alat Peraga Lidi

Dapat disimpulkan bahwa jumlah keseluruhan dari lidi yang dibeli Andre sebanyak 9 biji lidi seperti Gambar 2.

f. Pada saat pembelajaran kelompok, guru dapat menghampiri kelompok yang mengalami kesulitan dalam pemecahan masalah yang diberikan.

g. Setelah menemukan pemecahan masalah yang diberikan, guru dapat meminta perwakilan kelompok yang sudah menyelesaiakan soal yang diberikan untuk menjelaskan hasilnya di depan kelas untuk meningkatkan keaktifan siswa.

h. Guru menanyakan kepada siswa yang lain apakah sudah memahami solusi yang benar sehingga terjadi diskusi.

Pembelajaran matematika menggunakan alat peraga seperti lidi, bertujuan untuk membentuk siswa berpikir secara luas, mengasah keterampilan siswa dalam memecahkan masalah, dan dapat meningkatkan keaktifan siswa dalam pembelajaran. Oleh karena itu, tingkat perkembang operasional konkret (7-11 tahun) memerlukan alat peraga dalam pembelajaran matematika materi penjumlahan sehingga siswa dapat menyerap materi dengan baik.

\section{SIMPULAN}

Menurut teori Piaget, guru matematika harus mengetahui tentang perkembangan kognitif siswanya. Hal tersebut dapat diamati dari keaktifan siswa atau ada tidaknya interaksi siswa dengan lingkungan. Tingkat perkembangan intelektual yang dilakukan oleh setiap individu meliputi tingkat sensosi-motor (01 tahun), pra-operasional (2-7 tahun), operasional konkret (7-11 tahun), dan 
operasional formal (11 tahun ke atas). Setiap tingkat usia hanya merupakan suatu aproksimasi. Setiap anak melalui semua tingakatan ini, namun dengan kecepatan yang berbeda-beda.

\section{UCAPAN TERIMA KASIH}

Penulis mengucapkan terima kasih kepada tim redaksi atas kritik, saran, dan perbaikan tampilan artikel ini. Terima kasih juga penulis sampaikan kepada semua pihak yang terlibat dalam penyusunan artikel ini, yaitu Program Studi Matematika Universitas Muria Kudus yang telah memfasilitasi penelitian ini sehingga dapat terlaksana dengan baik.

\section{DAFTAR PUSTAKA}

Alhaddad, I. (2012). Penerapan teori perkembangan mental Piaget pada konsep kekekalan panjang. Infinity Journal, 1(1), 31-44. https://doi.org/10.22460/infinity.v1i1.5.

Anti, A., et. al. (2017). Jurnal ilmu pendidikan LPMP Kalimantan Timur volume XI nomor 1, Juni 2017. Retrieved March 18, 2021, from Repositori Institusi, Kementerian Pendidikan dan Kebudayaan: http://repositori.kemdikbud.go.id/16549/.

Basri, H. (2018). Kemampuan kognitif dalam meningkatkan efektivitas pembelajaran ilmu sosial bagi siswa sekolah dasar. Jurnal Penelitian Pendidikan, 18(1), 1-9. https://doi.org/10.17509/jpp.v18i1.11054.

Biantoro, N. O. P. H., Kristanti, F., \& Mursyidah, H. (2020). Pengaruh penilaian kinerja dan kecerdasan emosional berdasarkan project based learning (PjBL) terhadap hasil belajar matematika siswa. Square: Journal of Mathematics and Mathematics Education, 2(2), 89-102. http://dx.doi.org/10.21580/square.2020.2.2.5257.

Gradini, E. (2013). Teaching mathematics with Piaget's theory. Visipena, 4(1), 17. https://doi.org/10.46244/visipena.v4i1.98.

Hasanah, Y. M., \& Jabar, C. S. A. (2017). Evaluasi program wajib belajar 12 tahun pemerintah daerah kota Yogyakarta. Jurnal Akuntabilitas Manajemen Pendidikan, 5(2), 228-239. https://doi.org/10.21831/amp.v5i2.8546.

Hidayati, K. (2012). Pembelajaran matematika usia SD/MI menurut teori belajar Piaget. Cendikia: Jurnal Kependidikan dan Kemasyarakatan, 10(2), 291308. https://doi.org/10.21154/cendekia.v10i2.417.

Ibda, F. (2015). Perkembangan kognitif: teori Jean Piaget. Jurnal Intelektualita, 3(1), 27-38.

Jaenudin, C. (2018). Pengajaran bahasa arab di taman kanak-kanak (tinjauan teori perkembangan kognitif Jean Piaget). Lisanuna: Jurnal Ilmu Bahasa Arab dan Pembelajarannya, 8(1), 32-44. http://dx.doi.org/10.22373/l.v8i1.3475.

Juwantara, R. A. (2019). Analisis teori perkembangan kognitif Piaget pada tahap anak usia operasional konkret 7-12 tahun dalam pembelajaran matematika. 
Al-Adzka: Jurnal Ilmiah Pendidikan Guru Madrasah Ibtidaiyah, 9(1), 27-34. https://doi.org/10.18592/aladzkapgmi.v9i1.3011.

Lefa, B. (2014). The Piaget theory of cognitive development: an educational implications. Educational psychology, 1(9), 1-8.

Manullang, M. (2014). Manajemen pembelajaran matematika. Jurnal Pendidikan dan Pembelajaran, 21(2), 208-214.

Mauluah, L. (2012). Permainan dan alat peraga pada pembelajaran matematika tingkat SD/MI. Al-Bidayah: Jurnal Pendidikan Dasar Islam, 4(2), 173191.

Mu'min, S. A. (2013). Teori pengembangan kognitif Jean Piaget. Al-Ta'dib: Jurnal Kajian Ilmu Kependidikan, 6(1), 89-99.

Ojose, B. (2008). Applying Piaget's theory of cognitive development to mathematics instruction. The Mathematics Educator, 18(1). 26-30.

Rizkita, K., \& Supriyanto, A. (2020). Komparasi kepemimpinan pendidikan di Indonesia dan Malaysia dalam upaya peningkatan mutu pendidikan. Jurnal Akuntabilitas Manajemen Pendidikan, 8(2), 155-164. https://doi.org/10.21831/jamp.v8i2.32362.

Shadiq, F., \& Mustajab, N. A. (2011). Modul matematika SD program BERMUTU: penerapan teori belajar dalam pembelajaran matematika di SD. Retrieved March 18, 2021, from Repositori Institusi, Kementerian Pendidikan dan Kebudayaan: http://repositori.kemdikbud.go.id/15115/.

Sopian, A. (2016). Tugas, peran, dan fungsi guru dalam pendidikan. Jurnal Tarbiyah Islamiyah, 1(1), 88-97.

Sugriani, A. (2019). Upaya meningkatkan pemahaman konsep penjumlahan pecahan melalui pendekatan pendidikan matematika realistik Indonesia (PMR). Jurnal Didactical Mathematics, 1(2), 21-28. http://dx.doi.org/10.31949/dmj.v1i2.1294.

Sutrisno, S. (2015). Analisis kesulitan belajar siswa kelas II pada materi penjumlahan dan pengurangan bilangan. AKSIOMA: Jurnal Matematika dan Pendidikan Matematika, 6(1), 1-13.

Suwarto, S. (2017). Strategi pembelajaran operasi bilangan dengan benda konkrit.

UNION: Jurnal Ilmiah Pendidikan Matematika, 5(3), 285-294. https://doi.org/10.30738/.v5i3.1437. 